\title{
Peranan Majelis Taklim dalam Pembinaan Keberagamaan bagi Ibu Rumah Tangga
}

\author{
Oksy Almaidah $^{1}$, Novia Nengsih ${ }^{2}$ \\ ${ }^{1}$ Fakultas Ilmu Sosial, Universitas Negeri Padang, Padang \\ ${ }^{2}$ Fakultas Syariah, Institut Agama Islam Negeri Batusangkar, Batusangkar \\ Corresponding author, e-mail: oksy.almaidah99@gmail.com
}

\begin{abstract}
This study aims to determine and describe how the role of the taklim assembly in fostering religiosity in the aspect of worship for housewives; the role of the taklim assembly in fostering the religious reading of the Qur'an; the role of the taklim assembly in fostering religious diversity in the social aspect; and what are the supporting and inhibiting factors in religious development for housewives. The type of research used is qualitative research (field research), qualitative research methods are descriptive methods in the form of writing or words from people and observed behavior. Sources of data obtained from the congregation taklim assembly. To strengthen the research data obtained, the authors also took data through observation and documentation. All interview data were analyzed by collecting, reducing, presenting and ending with conclusion. The results of the study indicate that the role of the taklim assembly in religious development for housewives in various aspects, namely aspects of worship, the Koran, and social plays a very important role in broadcasting and developing Islam in society, especially for housewives.
\end{abstract}

Keywords: Taklim Council, Housewife Religious, Guidance

This is an open access article distributed under the Creative Commons 4.0 Attribution License, which permits unrestricted use, distribution, and reproduction in any medium, provided the original work is properly cited. (C2018 by author.

\section{Pendahuluan}

Menurut Mustofa (2019) dalam Nurul Mutia Kholida \& Rengga Satria, 2021 Pendidikan Islam yaitu pendidikan yang berasal dari ajaran islam atau segala sesuatu yang diajarkan berdasarkan ajaran islam itu sendiri dengan tujuan untuk pembinaan serta membentuk pribadi muslim yang beriman dan bertakwa kepada Allah SWT. Jenis pendidikan di Indonesia terbagi atas dua yaitu pendidkan formal, Informal dan pendidikan Nonformal. Ditinjau dari macam-macam lembaga pendidikan Islam Majlis taklim dapat dikategorikan sebagai lembaga pendidikan non formal(Bafadhol,2017). Dalam UUD No. 20 Tahun 2003, tentang hak dan kewajiban masyarakat disebutkan dalam pasal 8 bahwa: "Masyarakat berhak berperan serta dalam perencanaan, pelaksanaan, pengawasan dan evaluasi program pendidikan". Selanjutnya disebutkan dalam pasal 9 bahwa: "Masyarakat berkewajiban memberikan dukungan sumber daya dalam penyelenggaraan pendidikan".

Majelis taklim merupakan kumpulan dari beberapa kelompok atau suatu komunitas muslim yang melakukan kegiatan pendidikan dan pengajaran yang mempelajari tentang agama Islam (Sarbini,2014).Majelis taklim sebagai sarana dakwah maupun tabligh yang Islami dapat berperan sebagai wadah pembinaan bahkan peningkatan kualitas hidup umat Islam yang sesuai dengan tuntutan ajaran Islam yaitu al-qur'an dan as-sunnah. Peran majelis taklim secara fungsional yaitu untuk mengokohkan landasan hidup manusia khususnya dalam bidang keagamaan untuk meningkatkan kesejahteraan hidup manusia (Bakhtiar,2016). Keberagamaan merupakan aktivitas dalam melaksanakan ajaran agama dalam kehidupan sehari-hari yakni dalam aktivitas shalat, puasa dan berbakti kepada kedua orangtua, ukhwah, 
tolong-menolong antar sesama, dan segala aktivitas yang didasarkan pada nilai-nilai agama (Veriyanto, 2018).

Tujuan dari penelitian ini adalah untuk mengetahui bagaimana peranan majelis taklim dalam membina keberagamaan pada aspek ibadah bagi ibu rumah tangga di nagari koto nan duo kecamatan batang kapas, untuk mengetahui bagaimana peranan majelis taklim dalam membina keberagamaan baca qur'an bagi ibu rumah tangga di nagari koto nan duo kecamatan batang kapas, untuk mengetahui bagaimana peranan majelis taklim dalam membina keberagamaan pada aspek sosial bagi ibu rumah tangga di nagari koto nan duo kecamatan batang kapas, untuk mengetahui faktor pendukung dan penghambat dalam pembinaan keberagamaan bagi ibu rumah tangga di nagari koto nan duo kecamatan batang kapas.

Adanya kegiatan majelis taklim dalam lingkungan masyarakat dapat memperlihatkan akan kebutuhan dan adanya hasrat dari masyarakat itu sendiri dalam pengetahuan agama secara lebih luas. Seperti halnya untuk mengatasi suatu masalah yang terjadi dalam hidup agar dapat menciptakan hidup yang lebih baik. Untuk meningkatkan suatu tuntutan jamaah serta peran pendidikan nonformal, membangkitkan semangat serta upaya dari ulama dan anggota masyarakat agar dapat memperbaiki, mengangkat, mengembangkan kualitas, dan kesanggupan sehingga keberadaan dari majelis taklim dapat melakukan tanggungjawab serta fungsinya dengan baik (Rukiati \& Hikmawati, 2016).

Oleh karena itu peranan majelis taklim dapat memberikan kontribusi pada masyarakat untuk menanamkan bahkan meningkatkan pengetahuan pendidikan agama dalam masyarakat khususnya bagi ibu rumah tangga di nagari koto nan duo kecamatan batang kapas. Majelis taklim memiliki peran penting dalam mengembangkan konsep keagamaan yang ada di dalam lingkungan masyarakat. Kegiatan majelis taklim bisa dilaksanakan dimana saja dan bisa diikuti oleh kalangan bapak maupun Ibu. Tapi dalam dalam penelitian saya ini kegiatan majelis taklim di khususkan untuk para ibu-ibu saja terutama ibu rumah tangga. Dengan adanya kegiatan majelis taklim ini khususnya di Nagari Koto Nan Duo Kecamatan Batang Kapas dapat berperan penting dalam menambah wawasan mengenai pengetahuan keagamaan ibu-ibu yang ada di Nagari tersebut.

Majelis taklim memilki peran penting dalam mengembangkan dakwah islam. Karena majelis taklim memiliki makna dan tujuan yang baik dalam penyiaran agama Islam dan juga pengembangan bagi masyarakat dalam keagamaan terutama bagi kaum ibu-ibu di semua kalangan masyarakat. Oleh karena itu dengan adanya pembinaan keagamaan di lingkungan masyarakat terutama bagi ibu rumah tangga, mereka akan mendapatkan pengetahun dan pecerahan mengenai ilmu keagamaan yang lebih luas baik untuk dirinya sendiri dan lingkungan keluarga. Namun realitas yang terjadi di lapangan bahwa masih ada ibu-ibu majelis taklim yang mengikuti kajian yang tidak tahu dalam pengetahuan keagamaan. Seperti dalam beribadah, baca qur'an serta hubungan sosial yang ada di dalam masyarakat.

Adapun perbandingan masalah penelitian terdahulu dengan penelitian saya, yaitu Jurnal ilmiah yang ditulis oleh Indasari, Surni Kadir dan Normawati yang berjudul tentang Peranan Majelis Taklim Baabul Jannah dalam Meningkatkan Pemahaman Agama pada Masyarakat Desa Doulan Kecamatan Bokat kabupaten Boul, permasalahannya yaitu kurangnya pemahaman agama masyarakat di desa doulan kecamatan boukat kabupaten boul.Jurnal ilmiah yang ditulis oleh Oyo Bariah, Iwan Hermawan, dan H.Tajuddin Nur yang berjudul tentang Peranan Majelis Taklim dalam Meningkatkan Ibadah bagi Masyarakat di Desa Telukjambe Karawang, masalah dalam penelitian ini yaitu kurangnya pegetahuan ibadah pada masyarakat didesa teluk jambe, dan majelis taklim dijadikan lembaga alternative bagi 
mereka yang tidak memiliki cukup tenaga, waktu, dan kesempatan dalam menimba ilmu agama dijalur pendidikan formal.Jurnal ilmiah yang ditulis oleh Irmawati Ibrahim, Abd. Hamid Isa dan Yakob Napu yang berjudul Peran Majelis Taklim Nurul Iman dalam Meningkatkan Kehidupan Beragama, masalah dalam penelitian ini yaitu kurangnya penegtahuan dalam kehidupan beragama pada masyrakat.

\section{Metode}

Jenis penelitian yang digunakan adalah penelitian kualitatif (field research). Menurut Strauss dan Corbin penelitian kualitatif merupakan suatu jenis penelitian yang hasil pemikirannya tidak di dapatkan maupun diperoleh melalui hitungan angka atau statistik (Afrizal, 2014). Penelitian kualitatif digunakan untuk mendapatkan suatu pemahaman yang lebih mendalam tentang suatu peristiwa tertentu di dalam lingkungan masyarakat maupun di dalam kelompok masyarakat itu sendiri. Suatu hasil penelitian berupa data deskriptif yang berbentuk suatu penjelasan atau pendapat tetang suatu hal yang mendalam serta secara menyeluruh mengenai suatu aspek tertentu. Penelitian kualitatif bertujuan untuk melakukan dan melakukan analisis pada data kualitatif, yakni data yang bukan merupakan angka-angka (Wijayanti, 2013). Sedangkan pendekatan yang digunakan adalah kualitatif. Penelitian yang mengutamakan pada data yang berdasarkan pada hasil yang di dapatkan atau yang di sampaikan oleh responden berdasarkan dari data yang dikumpulkan yang berupa kata-kata, deskriptif dan tidak berupa angka-angka. Misalnya, tindakan, perilaku, motivasi dan tanggapan (Sugiyono, 2009).

Metode penelitian kualitatif adalah metode deskriptif. Filosofi penelitian kualitatif di dalam penelitian ini adalah kegiatan yang berusaha untuk mengamati, melakukan analisa, menggambarkan/memaparkan dan menentapkan atau menentukan identitas (benda, orang dan sebagainya) suatu kejadian yang alami (Agustinova, 2015). Suharsimi Arikunto (2013) Instrumen penelitian merupakan alat bantu yang digunakan dalam melakukan penelitian oleh peneliti untuk dapat mengumpulkan suatu data agar kegiatan tertentu tersusun secara sistematis atau terstruktur dan terarah. Instrument penelitian dalam penelitian ini adalah peneliti sendiri. Teknik pengumpulan data dalam penelitian ini menggunakan metode wawancara, metode observasi, metode dokumentasi.

Teknik yang digunakan untuk pengecekan keabsahan data adalah teknik triangulasi. Adapun triangulasi yang dipakai dalam pengecekan keabsahan data dalam penelitian adalah Triangulasi sumber, yaitu untuk mengetahui kredibilitas data dengan melihat kembali atau mencocokkan kembali data di dapat melalaui beberapa sumber. Penulis menggunakan triangulasi sumber dengan tujuan untuk melakukan perbandingan apa di sampaikan oleh pengurus majelis taklim, ibu-ibu rumah tangga mengenai kegiatan majelis taklim. Kemudian Triangulasi teknik yaitu untuk menguji keasliaan suatu data dengan cara melihatkan kembali data kepada sumber yang sama dengan menggunakan teknik yang berbeda. Penulis menggunakan data triangulasi teknik yaitu bertujuan untuk membandingkan data yang diperoleh seperti halnya membandingkan hasil wawancara dengan observasi maupun dokuemntas, dan Triangulasi waktu yaitu cara untuk mengetahui perihal yang dapat dipercaya pada sebuah data dapat dilaksanakan pada waktu tertentu melalui wawancara, observasi atau hal lainnya dlm situasi yang berbeda, serta ditrmukannya kredibilitas data tersebut (Sugiyono,2013). Dalam pengertian ini peneliti menggunakan teknik pengabsahan data yaitu triangulasi sumber dan triangulasi teknik.

\section{Hasil dan Pembahasan}

Menurut kustini (2007) majelis taklim memilki tujuan salah satunya adalah untuk menjadikan manusia atau keadaan untuk kearah yang lebih baik dengan cara mengajarkan 
tentang Islam yang benar sesuai dengan Al-qur'an dan As-sunah sebagai pedoman hidup baik bagi individu, masyarakat dan Negara.

Adapun berbandingan penelitian terdahulu dengan penelitian saya dari segi hasil, yaitu Jurnal ilmiah yang ditulis oleh Indasari, Surni Kadir dan Normawati yang berjudul tentang Peranan Majelis Taklim Baabul Jannah dalam Meningkatkan Pemahaman Agama pada Masyarakat Desa Doulan Kecamatan Bokat kabupaten Boul, peranan yang dilakukan oleh majelis taklim Baabul Jannah dalam meningkatkan pemahaman masyarakat desa doulan kecamatan bokat kabupaten boul yaitu mengadakan pengajian rutin, tadarus al-qur'an yasinan dan dzkikr bersama, dan khattam al-qur'an 30 juz serta penanaman nilai nilai sosial. Dan diharapkan mampu memberikan kontribusi kepada masyarakat guna untuk menambah wawasan tentang ajaran agama islam, agar tidak ada lagi keyakinan atau pemahaman yang disalah tafsirkan oleh masyarakat yang merujuk kepada kemusrikan dan menduakan Allah. Jurnal ilmiah yang ditulis oleh Oyo Bariah, Iwan Hermawan, dan H.Tajuddin Nur yang berjudul tentang Peranan Majelis Taklim dalam Meningkatkan Ibadah bagi Masyarakat di Desa Telukjambe Karawang, hasil penelitian ini membuktikan bahwa keberaaan majelis taklim mampu memberikan tambahan ilmu dan pengetahuna bagi masayrakat dalam meningkatkan ibadah dan akhlak masyarakat dengan kategori baik. Jurnal yang ditulis oleh Irmawati Ibrahim, Abd. Hamid Isa dan Yakob Napu yang berjudul Peran Majelis Taklim Nurul Iman dalam Meningkatkan Kehidupan Beragama, hasil dari penelitian ini menunjukkan bahwa anggota majelis taklim nurul iman agar biasa mengoptimalkan kinerja, sehinga peran majelis taklim dapat dioptimalkan. Untuk para masyarakat lebih mempraktekkan ilmu-ilmu tentang majelis taklim yang telah di dapatkan dalam kehidupan sehari-hari.

1. Peranan Mejelis Taklim dalam Pembinaan Keberagamaan pada Aspek Ibadah bagi Ibu Rumah tangga di Nagari Koto Nan Duo Kecamatan Batang Kapas.

Majelis taklim merupakan suatu wadah untuk belajar ilmu Agama. Majelis taklim memilki peran yang sangat penting yaitu sebagai tempat perhimpunan dalam membina dan mengembangkan kehidupan Beragama bagi manusia dalam rangka untuk menciptakan manusia yang bertakwa dan beriman kepada Allah SWT (Abu Ahmadi,2009). Tujuan dari pembinaan ibadah adalah sebagai bentuk menunaikan rukun islam yang kedua yaitu melaksnakan shalat dan yang Terlihat dari kegiatankegiatan yang di laksanakan oleh ibu-ibu majelis taklim di Nagari Koto Nan Duo. Peran Majelis taklim yang selama ini sangat baik dalam memberikan pembinaan jiwa maupun mental rohaniah bagi kaum wanita sehingga semangat dalam belajar dan mengerjakan ibadah.

Ibadah merupakan suatu ketaatan seorang hamba kepada Allah Subhanahu Wa Ta'ala. Ibadah mencakup semua kegiatan yang dilakukan oleh manusia dengan tujuan tunduk/beribadah kepada Allah dengan niat untuk mencari Ridho Allah Subhanahu Wa Ta'ala yang mana hal tersebut di pandang sebagai Ibadah (Abidin, 2020).

Firman Allah:

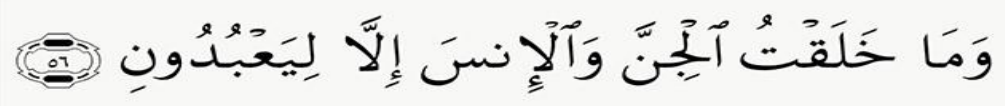

Artinya: "Tidaklah Ku ciptakan jin dan manusia melainkan untuk mengabdi kepada-Ku (Al-Dzariyat:56)."

Kegiatan majelis taklim dalam pembinaan agama dalam aspek ibadah yang dilaksanakan dalam model bimbingan shalat yang pada intinya pembinaan yang 
dilakukan dengan cara teori dan praktek dengan tujuan dari pembinaan ibadah adalah untuk mengamalkan serta menunaikan rukun islam (Rahmat,2018).

Peranan majelis taklim dalam membina keberagamaan bagi ibu rumah tangga di Nagari koto Nan Duo Kecamatan Batang Kapas cukup mengalami perubahan ke arah yang lebih baik. Seperti yang terdapat pada hasil temuan penelitian dan juga wawancara serta observasi yang telah dilakukan oleh peneliti masih ada ibu-ibu yang tidak tahu cara shalat fardhu dan shalat jenazah. Tapi dengan adanya pembinaan yang di lakukan di majelis taklim ibu-ibu tersebut antusias untuk tetap belajar satu sama lain. Selain itu dalam aspek ibadah para jamaah juga semangat dalam meghafal doa-doa. Dengan adanya pembinaan yang dilakukan secara bertahap memberikan dampak perubahan pada ibu-ibu yang mengikuti kajian. Dapat dipahami bahwa peranan majelis taklim dalam pembinaan keberagamaan pada aspek ibadah sangat penting dalam menumbuhkan dan menambah wawasan pengetahuan keagaaman bagi ibu rumah tangga di Nagari Koto Nan Duo kecamatan Batang Kapas yang telah memberikan perubahan cukup baik.

Berdasarkan hasil observasi dan hasil wawancara yang peneliti lakukan dapat di lihat bahwa majelis taklim di nagari koto nan duo kecamatan batang kapas dalam pembinaan keberagamaan bagi Ibu rumah tangga dalam aspek ibadah terdapat perubahan yang baik dan juga dari hasil wawancara sangat antusias. Dari hasil tersebut ibu-ibu rumah tangga yang mengkuti kegiatan majelis taklim menjadi tahu dan bisa dalam melaksanakan ibadah-ibadah sunnah dan juga dari yang tidak tahu cara shalat jenazah kemudian menjadi tahu karna adanya pembinaan keagamaan dari kegiatan majelis taklim.

2. Peranan Majelis Taklim dalam Pembinaan Keberagamaan Baca Qur'an bagi Ibu Rumah Tangga di Nagari Koto Nan Duo Kecamatan Batang Kapas.

Pembelajaran baca qur'an merupakan sebuah pembelajaran yang sangat penting untuk dipelajari sampai kapanpun oleh umat manusia yang beragama islam, karena membaca al-qur'an merupakan salah satu pintu masuk untuk menuju pada pengetahuan Islamiah seperti halnya akhlak,akidah, Ibadah dan lain-lain, dan juga merupakan kunci utama dalam memberikan petunjuk kepada umat islam( ma'mun, 2018). Sebagaimana wahyu yang pertama diturunkan oleh Allah kepada Nabi Muhammad SAW yang terdapat dalam qur'an surah Al-'alaq ayat 1-5 :

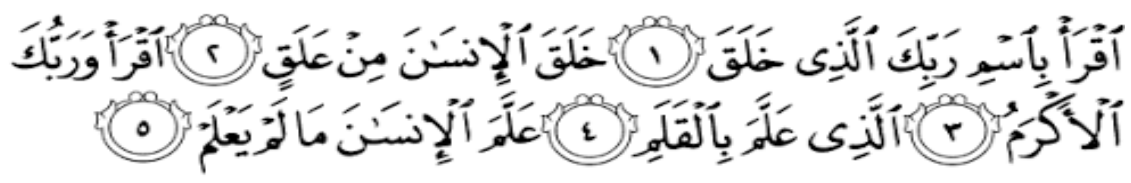

1. Bacalah dengan (menyebut) nama Tuhanmu yang Menciptakan,

2. Dia telah menciptakan manusia dari segumpal darah.

3. Bacalah, dan Tuhanmulah yang Maha pemurah,

4. Yang mengajar (manusia) dengan perantaran kalam

5. Dia mengajar kepada manusia apa yang tidak diketahuinya.

Peranan majelis taklim dalam aspek baca qur'an seperti yang diketahui dari hasil temuan penelitan bahwa masih ada dari beberapa ibu-ibu jamaah majelis taklim yang belum bisa membca al-quran diketahui masih ada yang iqra. Tapi dengan adanya pembinaan dari kegiatan majelis taklim adanya perubahan yang dialami oleh para ibu majelis taklim dari yang tidak tahu membca al-quran yang awalnya hanya 
dari iqra kemudian bisa membaca al-qur'an, dan dengan adanya pembinaan keagamaan yang dilakukan pada bidang baca qur'an ibu-ibu majelis taklim memilki peranjakkan kea rah yang lebih baik dari yang bacaan al-qur'annya yang belum sesuai dengan kaidah huruf dan tajwid dengan adanya pembinaan yang dilakukan dalam pengajian ada beberapa ibu majelis taklim bacaannya sudah mulai cukup baik dari pembinaan yang dilakukan satu sama lain dalam anggota dan juga bimbingan dari Ustadz.

Berdasarkan dari hasil observasi dan wawancara yang peneliti lakukan dapat di lihat bahwa peranan majelis taklim di Nagari Koto Nan Duo Kecamatan Batang Kapas dalam bidang baca qur'an mengalami perubahan yang baik secara berangsurangsur. Ibu-ibu yang masih iqra kemudian bisa membaca al-qur'an, dan yang sudah bisa membaca al-qur'an walaupun sepenuhnya baik terus semangat mempelajari tajwid dan tempat keluarnya huruf yang benar.

3. Peranan Majelis Taklim dalam Membina Keberagamaan pada Aspek Sosial bagi Ibu Rumah Tangga di Nagari Koto Nan Duo Kecamatan Batang Kapas.

Adanya kegiatan bakti sosial merupakan salah satu wujud dari rasa kemanusiaan karena dengan adanya kegiatan tersebut dapat mempererat hubungan silaturahmi antar sesama. Dengan adanya kegiatan bakti sosial yang dilakukan oleh jamaah majelis taklim dapat mewujudkan rasa peduli, tolong menolong serta rasa cinta kasih antar sesama. Tujuan dari kegiatan ini adalah dapat memberikan motivasi kepada lingkungan masyarakat dalam mempererat hubungan kekeluargaan antar masyarakat tersebut(Mardia, 2017).

Memilki hubungan yang baik antar sesama di dalam lingkungan masyarakat itu sangat penting. Demi menjaga keutuhan dan keharmonisan antar sesama manusia. Setelah mengikuti kegiatan sosial ibu-ibu jamaah majelis taklim juga mendapatkan semangat baru di dalam kehidupan sehari-hari. Dengan adanya kegiatan bersihbersih menumbuhkan semangat bagi ibu-ibu juga untuk menjaga kesehatan dalam lingkungan kelaurganya. Selain itu, dengan adanya kegiatan sosial membuat hubungan antara lingkungan masyarakat menjadi lebih baik dan memilki sikap toleransi dan saling menghargai satu sama lain.

Berdasarkan hasil Observasi dan hasil wawancara dapat dilihat bahwa dengan adanya kegiatan sosial menumbuhkan semangat bagi para jamaah untuk terus menjaga kebersihan dan juga menjaga kekompakan dan hubungan antara para anggota dan juga lingkungan masyarakat.

\section{Faktor Penghambat dan Pendukung dalam Pembinaan Keberagamaan bagi Ibu} Rumah Tangga di Nagari Koto Nan Duo Kecamatan Batang Kapas.

Setiap lembaga atau organisasi yang dalam menjalankan suatu kegiatan pasti akan ada faktor pendukung dan rintangan atau hambatannya. Begitupun yang yang dialami oleh jama'ah Majelis Taklim di Nagari Koto Nan Duo Kecamatan Batang Kapas.

\section{a. Faktor pendukung}

1) Ketua Majelis Taklim mengatakan bahwa dana juga merupakan faktor pendukung dalam kegiatan majelis taklim. Kegiatan suatu organisasi atau lembaga akan berjalan baik jika juga mempunyai dana yang memadai/cukup. Sumber dana yang ada diperoleh dari uang kas yang dikumpulkan oleh para anggota setiap semingu sekali. Pembayaran 
uang kas tetap berjalan atau terhitung walau ada dari anggota yang tidak hadir dalam pengajian akan membayar double. Jadi dari segi dana tidak mengalami kekurangan.

2) Ibu Ilef selaku penasihat majelis taklim menyatakan Adanya dukungan dari pemerintah daerah seperti partai politik yang memberikan bantuan berupa bahan kain yang dijadikan baju seragam oleh para jamaah majelis taklim hal itu juga mengurangi beban dari segi perdanaan bagi anggota majelis taklim dan juga membentuk kekompakkan dari para jamaah.

\section{b. Faktor Penghambat}

1) Ibu Sarnileli selaku sekretaris majelis taklim mengatakan bahwa kurangnya kesadaran dari anggota majelis taklim untuk terus aktif dalama mengikuti pengajian majelis taklim dikarenakan kesibukan dari aktivitas anggota masing-masing baik itu berupa pekerjaan atau urusan dalam rumah tangga. Karena kebanyakan dari ibu-ibu majelis taklim ini yang berprofesi dari ibu rumah tangga yang memang lebih mengutamakan dalam megurus pekerjaan rumah tangga. Oleh karena itu, pengurus dan penasihat dari majelis taklim berupaya untuk terus mengajak para jamaah untuk terus hadir dalam pengajian agama ini.

2) Pernyataan dari ibu Lefriani Penasihat Majelis taklim, pengaruh lingkungan sangat berdampak dalam lingkungan masyarakat.karena ibu-ibu majelis taklim yang sudah ikut pengajian terkadang masih juga terpengaruh tidak ikut datang ke pengajian disebabkan karena pengaruh gosip dan juga ada dari ibu-ibu anggota majelis taklim yang tidak berhubungan baik. Karena itu kami selaku pengurus majelis taklim berupaya memberikan pengertian kepada para jamaah tujuan adanya majelis taklim apa dan memberikan masukan ketika adanya kegiatan sosial di lingkungan masyarakat.

\section{Simpulan}

Berdasarkan hasil penelitian maka dengan berpedoman kepada tujuan dan rumusan masalah penelitian dapat disimpulkan bahwa majelis taklim merupakan suatu wadah lembaga organisasi keagamaan yang terdiri dari beberapa kumpulan masyarakat yang mempelajari tentang pendidikan Islam dan bersifat nonformal. Peranan Majelis taklim dalam Membina Keberagamaan pada Aspek Ibadah bagi Ibu Rumah Tangga di Nagari Koto Nan Duo Kecamatan Batang Kapas, yaitu melatih dan melakukan pembinaan kepada ibu-ibu mengenai shalat fardhu dan shalat jenazah. Peranan Majelis taklim dalam Membina Keberagamaan Baca Qur'an bagi Ibu Rumah Tangga di Nagari Koto Nan Duo Kecamatan Batang Kapas, yaitu melakukan pembinaan kepada ibu-ibu yang tidak bisa membaca alqur'an baik itupun yang masih iqra sehingga memberikan dampak baik pada ibu-ibu yang dalam proses belajar. Peranan Majelis taklim dalam Membina Keberagamaan pada Aspek Sosial bagi Ibu Rumah Tangga di Nagari Koto Nan Duo Kecamatan Batang Kapas, yaitu mempererat silaturahmi antar sesama dan menjaga kebersihan lingkungan sekitar dan keluarga. Faktor Pendukung dan Penghambat dalam Pembinaan Keberagamaan bagi Ibu Rumah Tangga di Nagari Koto Nan Duo Kecamatan Batang Kapas yaitu Faktor Pendukung yaitu dana dan sukungan pemerintahan setempat dan Faktor Penghambat yaitu faktor lingkungan dan kemauan ibu - ibu majelis taklim. 


\section{Daftar Kepustakaan}

Afrizal. (2014).Metode Penelitian Kualitatif: Sebuah Upaya Mendukung Penggunaan Metode Penelitian Kualitatif dalam Berbagai Disiplin Ilmu. Jakarta: Rajawali Pers.

Abidin, Zaenal. (2020). Fiqh Ibadah. Yogyakarta: Deepublish.

Abuddin, Nata. (2009). Akhlak tasawuf. Jakarta : Raja Grafindo Persada.

Agustinova, Eko Danu. (2015). Memahami Metode Penelitian Kualitatif: Teori dan Praktik. Yogyakarta: Calpulis.

Arikunto, S. (2013). Prosedur Penelitian: Suatu Pendekatan Praktik. Jakarta: Rineka Cipta.

Azmi, Muhammad. (2006). Pembinaan Akhlak Anak Usia Pra Sekolah. Yogyakarta: Belukar.

Bafadhol, I. (2017). Lembaga Pendidikan Islam Di Indoesia. Jurnal Edukasi Islami Jurnal Pendidikan Islam, 06(11), 59-72.

Bakhtiar. (2016). Psikologi Agama. Bengkulu: IAIN Bengkulu.

Bariah,O. Hermawan, I.\& Nur, H.T. (2012). Peran Majelis Taklim dalam Meningkatkan Ibadah bagi Masyarakat di Desa Telukjambe Karawang. Solusi, Vol 10(21) 1-10.

Cahaya, Andi Intan. (2013). Fiqh Muamalah. Makassar: Alauddin University Press.

Djamaluddin,A., \& Fuat,N. S. (2010). Psikologi Islam. Yogyakarta: Pustaka Pelajar.

Fatih Mutiah. (2014). Peran Ganda Mahasiswa UIN Sunan Kalijaga Yogyakarta sebagai Ibu Rumah Tangga (Kajian Anchoring dalam Pengambilan Keputusan). Skripsi. Yogyakarta: UIN Sunan Kalijaga.

Helmawati. (2013). Pendidikan Nasional dan Optimalisasi Majelis Ta'lim. Jakarta: Rineka Cipta.

Indriani, J. (2021). Hubungan Efektifitas Pengajian Ibu-Ibu Rumah Tangga dengan Perilaku Keberagamaan Mereka. Universitas Islam Negeri SunanGunung Djati.

Indasari. Kadir,S. \& Normawati. (2020). Peranan Majelis Taklim Baabul Jannah dalam Meningkatkan Pemahaman Agama pada Masyarakat Desa Doulan Kecamatan Bokat Kabupaten Boul. Jurnal Ilmu Kependidikan dan Keislaman, 15(01), 1-10.

Ibrahim. I. Isa, Abd. Hamid \& Napu, Y. (2020). Peran Majelis Taklim Nurul Iman dalam Meningkatkan Kehidupan beragama. Jambura Journal Community Empowerment (JJCE), 1(1). 42-49.

Kholida, N.M \& Satria, R. (2021). Peran Kegiatan Pengajian Sebagai Wadah Pelaksanaan Pendidikan Islam Berbasis Masyarakat. Jurnal Pendidikan Tambusai Vol 5 (2).

Kustini. (2007). Peningkatan Peran Serta Masyarakat dalam Pendalaman Ajaran Agama Melalui Majelis Taklim. Jakarta: Puslitbang Kehidupan Kebersamaan.

Lexy J. M.(2009). Metodologi Penulisan Kualitatif. Bandung: Rosdakarya.

Ma'mun, M. A. (2018). Kajian Pembelajaran Baca Tulis Al-Qur'an. Jurnal Pendidikan Islam, 
$4(1), 52-62$.

mardia. (2017). Peranan Sosial Majelis Ta'lim Terhadap Peningkatan Minat Ibu Rumah Tangga pada Masyarakat Bajeng Kabupaten Gowa.

Nasrullah, R. (2017). Media Sosial: Perspektif Komuniasi, Budaya < dan Sosioteknologi. Bandung: Remaja Rosdakarya.

Purwodarminto . (2010). Kamus umum Bahasa Indonesia. Jakarta : Balai Pustaka.

Rahmat, A. (2018). Peranan Majelis Taklim Al-Munawwarah dalam Pembinaan Masyarakat diKelurahan Mosso Dhua Kecamatan Sendana Kabupaten Majene Provinsi Sulawesi Barat. Universitas Islam Negeri Alauddin Makassar.

Rukiyati, Enung K \& Hikmawati, Fenti.(2006). Sejarah Pendidikan Islam di Indonesia. Bandung:CV Pustaka Setia.

Sarbini, Ahmad. (2014). Internalisasi Nilai Keislaman Melalui Majelis Taklim. Jurnal Ilmu Dakwah 5(16).

Sari, Nur Indah. (2019). Strategi Dakwah Majelis Taklim Permata dalam Membina Ibadah Masyarakat di Desa Moncongloe Bulu Kecamatan Moncongloe Kabupaten Maros. Makassar: UIN Alauddin Makassar.

Sugiyono.(2009). Metode Penelitian Kuantitatif, Kualitatif dan $R \& D$. Bandung : Alfabeta.

Sugiyono. (2013). Metode Penelitian Pendidikan. Bandung: Alfabeta.

Taqiyyudin, Mashuri. (2014). Konsep Dasar Pendidikan Luar Sekolah. Cirebon: Pangger Publishing.

Veriyanto. Joni. (2018). Peran majelis taklim dalam pembinaan keberagamaan ibu rumah tangga di desa pekalongan lampung timur. Skripsi (Online). Lampung: Institut Agama Islam Negeri Metro.

Wahyu. Asri. (2013). Peran Ibu Rumah Tangga Dalam Meningkatkan Kesejahteraan Keuarga. Skripsi. Semarang: Universitas Negeri Semarang.

Wijayanti, Yenni. (2013). Proses Komunikasi Interpersonal Ayah dan Anak dalam Menjaga Hubungan. Junal E-komunikasi, Vol 1 (3).

Zailani, Ahmad. (2019). Pembinaan Keagamaan Melalui MajlisTa'lim Al-Hidayah Di Desa Bono Tapung Kecamatan Tandum Kabupaten Rohan Hulu Riau. Skripsi Tidak Diterbitkan. Riau: Universitas Islam Negeri SUSKA Riau. 